\title{
Boswellia and Commiphora Species as a Resource Base for Rural Livelihood Security in the Horn of Africa: A Systematic Review
}

\author{
Badal Ahmed Hassan ${ }^{1, *}$, Edinam K. Glover ${ }^{2}$, Olavi Luukkanen ${ }^{1}$, Markku Kanninen ${ }^{1}(\mathbb{D}$ and \\ Ramni Jamnadass ${ }^{3}$ \\ 1 Viikki Tropical Resources Institute (VITRI), Department of Forest Sciences, University of Helsinki, \\ P.O. Box 27, FI-00014 Helsinki, Finland \\ 2 Faculty of Law, University of Helsinki, P.O. Box 4, FI-00014 Helsinki, Finland \\ 3 World Agroforestry Centre (ICRAF), United Nations Avenue, Gigiri, P.O. Box 30677-00100 Nairobi, Kenya \\ * Correspondence: badal.hassan@helsinki.fi; Tel.: +358-45-121-2700
}

Received: 18 May 2019; Accepted: 28 June 2019; Published: 1 July 2019

\begin{abstract}
The dryland vegetation and particularly the Acacia-Commiphora woodlands support the livelihoods of approximately 52 million rural households in the Horn of Africa. Aromatic resins are valuable non-wood forest products (NWFPs) derived from Boswellia and Commiphora species in the drylands of this region. The study seeks to answer the following main questions: "What are the ecological and livelihood roles of resin producing species, and the role that people have in either degrading or restoring these ecosystems?" "Who are the participants in frankincense and myrrh production, processing, and trade, and how do these people interact?" "What is the current and potential future economic impact of frankincense and myrrh production and trade at the household level?" "What are the barriers to enhanced economic outcomes?" The study involves the use of PRISMA method-a systematic methodology to identify, select and analyze the recent literature on aromatic resins in relation to such factors as socio-economic situation, livelihood security, value chain, climate change adaptation, ecology and sustainable development in the Horn of Africa. Systematic identification of publications was conducted using several sources, including but not limited to electronic databases for literature search. Web of Science, Social Science Citation Index and Google Scholar and various scientific journals were investigated using search terms and restrictions. A total of 991 references were retrieved, but literature only published between 2003 to 2017 was selected, which led to the use of 51 works for full-text assessment. The results indicate that of the 51 selected studies, $45 \%$ focused on ecology and sustainable management, $31 \%$ on economic contribution and livelihood security, $20 \%$ on production and value chain development, and $4 \%$ on climate change adaptation and mitigation. It could be concluded that farmers' adoption of Boswellia and Commiphora species as economic tree crops in the Horn of Africa has a distinct role in biodiversity conservation and climate change adaptation by contributing to the sustainability of ecosystem functioning as well as improving household incomes and the rural livelihood security in general, and thereby facilitating poverty alleviation.
\end{abstract}

Keywords: aromatic resins; frankincense and myrrh; livelihood security; climate change adaptation and mitigation; non-wood forest products; rural development

\section{Introduction}

Aromatic resin producing species of Boswellia and Commiphora belong to the family Burseraceae. Along with the genus Acacia these trees are widely distributed in the drylands of the Horn of Africa. 
In this study, the Horn of Africa region is defined as comprising eight countries, namely Djibouti, Eritrea, Ethiopia, Kenya, Somalia, Sudan, South Sudan and Uganda (Figure 1). Woodlands, wooded grasslands and the Somalia-Masai Acacia-Commiphora deciduous bushland and thicket are the main vegetation types in the drylands of the Horn of Africa, with over 2500 different plant species of which approximately half are endemic in the region [1] affecting $26 \%$ of the rural population, or about 52 million people [2]. These ecosystems provide environmental services as well as economically important products for rural communities, including numerous non-wood forest products for household consumption, livestock production and commercial uses. Within this group of products, gums and aromatic resins constitute the bulk of non-wood forest products (NWFPs) [3-7].

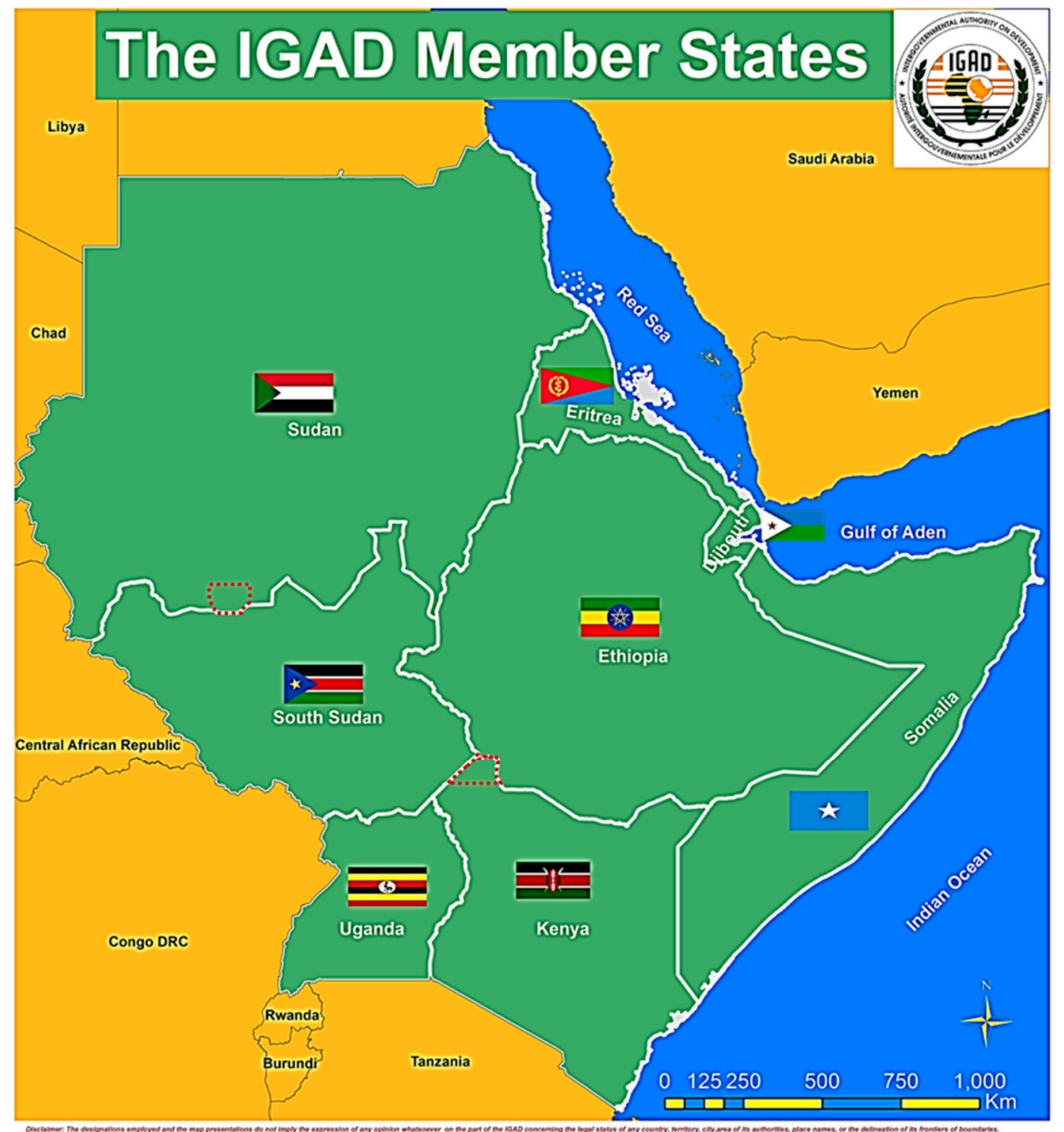

Figure 1. Map of countries making up the Horn of Africa [8].

Frankincense is a natural resin obtained from various species of the genus Boswellia, whereas myrrh resin (syn. malmal) is obtained from certain species of the genus Commiphora, particularly C. malmal, C. hadi and C. holiziana [9-13]. For millennia, the rural communities in the region have been harvesting and trading frankincense and myrrh for medicinal and cosmetic purposes as well as for cultural and religious ceremonies [14]. Aromatic resins are thus well established as commercial products, but there is a need for deeper analysis of associated value chains that could contribute to livelihood improvement, especially for poor households and risk groups [15-17]. Proper commercialization and market chain 
development for aromatic resins in the region could offer new economic opportunities and poverty reduction solutions.

There has been a process of marginalization of the rural communities in the drylands of the Horn of Africa [18]. Despite their present situation, the pastoral and agro-pastoral communities in the region remain relying on utilization of forest products from the ecosystem, both for their subsistence and cash needs (ibid.). However, there is high rate of ecosystem degradation in this region and, therefore, the populations of Boswellia and Commiphora species in the natural vegetation are declining rapidly [19].

The decline in commercially important tree species with a subsequent deterioration of rural livelihood opportunities has been attributed to ecosystem degradation caused by drought, excessive fuelwood harvesting and overgrazing, as well as to land conversion, improper resin tapping methods and insect damage. It has been argued that, due to the decline in the populations of these tree species, the sustainability of frankincense and myrrh production is at risk [20]. Sustainable management, clear political will, and scientific and development programmes that could promote the socio-economic significance of aromatic resin value chains at different levels are urgently needed [21].

Lack of accurate data for influencing decision makers to formulate appropriate policies and legislation to support the commodity development is the main obstacle to meeting the sustainable development and conservation objectives for Boswellia and Commiphora species and their products [22]. Athough several scientific studies have been conducted regarding the socio-economic and ecological importance of Boswellia and Commiphora species, none of them has systematically evaluated the socio-economic contributions of aromatic resins to national and regional economies [23].

Studies $[23,24]$ have also indicated that further work is needed to analyse the alternatives for sustainable management, production, processes and market linkages of frankincense and myrrh in the drylands of the Horn of Africa. An assessment of the value of aromatic resins to national and local revenues should also include factors that affect the production technology of frankincense and myrrh and the available management options [9].

Underlying assumptions in this review were, firstly, that proper commercialization and value-chain development of frankincense and myrrh are significant economic incentives to manage the dryland ecosystems sustainably, and, secondly, that Boswellia and Commiphora species as integrated components of agro-silvo-pastoral systems could significantly contribute to rural livelihoods and improve adaptability to climate change in the Horn of Africa. Against this background, the aim of this paper was to systematically review and summarize the recent literature in terms of socio-economic and ecological relevance of aromatic resins in this region. In addition, this study also explores strategies adopted by local people to adapt to climate change. The following questions guided the study: "What are the ecological and livelihood roles of resin producing species, and the role that people have in either degrading or restoring these ecosystems?" "Who are the participants in frankincense and myrrh production, processing, and trade, and how do these people interact?" "What is the current and potential future economic impact of frankincense and myrrh production and trade at the household level?" "What are the barriers to enhanced economic outcomes?"

\section{Materials and Methods}

The study employs a systematic and explicit methodology to identify, select and critically review the current literature on aromatic resins in the Horn of Africa. It analyses such factors as socio-economic situation, livelihood security, value chain, climate change adaptation, ecology and sustainable development. Criteria for considering studies for this review was based on the checklist of Preferred Reporting Items for Systematic reviews and Meta-Analyses (PRISMA) [25].

Systematic identification based on electronic databases utilized for the literature search were Web of Science, Social Science Citation Index and Google Scholar; on-going projects reported in national forest programmes, conference proceedings and university publications were also investigated. In addition, the following scientific journals were reviewed to find any articles not identified through 
keywords via electronic means: Journal of Arid Environments, Forest Policy and Economics, Forest Ecology and Management, Climate and Development, and International Forest Review.

The retrieved literature published between 2003 and 2017 was selected for analysis, which led to the use of 51 works for full-text assessment. Based on the research questions and criteria chosen, all 51publications were reviewed, within the Horn of Africa context, on the subject of ecological and livelihood roles of resin producing species, climate change adaptation, frankincense and myrrh value chains and economic contribution.

The information on socio-economic and ecological parameters was abstracted into a checklist for each of the studies fulfilling the search criteria. Factors considered were the location of the study, target population and main issue addressed, as well as the potential for further development of aromatic resin value chains. The lack of clarity in typology is most acute in the area of livelihood security and climate change adaptation, rendering it difficult to speak of socio-economic and ecological parameters of different aromatic resins value chains [26]. (Table 1) presents the search terms and restrictions.

Table 1. Search terms and restrictions.

\begin{tabular}{ccc}
\hline Domain & Description & Search terms \\
\hline Economic evaluation & $\begin{array}{c}\text { National and households } \\
\text { income }\end{array}$ & $\begin{array}{c}\text { Socio-economic contribution OR aromatic resins OR } \\
\text { frankincense OR myrrh OR household income OR } \\
\text { poverty alleviation }\end{array}$ \\
\hline Ecological evaluation & $\begin{array}{c}\text { State of dryland } \\
\text { ecosystems }\end{array}$ & $\begin{array}{c}\text { Desertification AND deforestation AND Boswellia and } \\
\text { Commiphora species drylands Horn of Africa }\end{array}$ \\
\hline Parameters & Setting & $\begin{array}{c}\text { Dibouti OR Eritrea OR Ethiopia OR Kenya OR Somali } \\
\text { OR South Sudan OR Sudan OR Uganda }\end{array}$ \\
\hline Publication dates & Focused parameters & $\begin{array}{c}\text { Adaptation to climate change rural livelihood security, } \\
\text { AND production AND processing AND marketing } \\
\text { channels of aromatic resins OR socio-economic } \\
\text { evaluation using outcomes in terms of household income } \\
\text { generated from aromatic resins }\end{array}$ \\
\hline
\end{tabular}

\section{Results}

The results show that about $45 \%$ of the studies selected for thorough analysis focused on ecology and sustainable management, $31 \%$ on economic contribution and livelihood security, $20 \%$ on production and value chain development, and $4 \%$ on climate change adaptation and mitigation. However, some of the publications fall under more than one of the selected parameters, as presented in (Table 2). 
Table 2. Aromatic resins with reference to ecological impacts, adaptation to climate change and rural livelihood security in the Horn of Africa (2003-2017).

\begin{tabular}{|c|c|c|}
\hline Themes & $\begin{array}{c}\text { Number of } \\
\text { Studies: } n=51\end{array}$ & References \\
\hline $\begin{array}{l}\text { Economic } \\
\text { contribution and } \\
\text { livelihood security }\end{array}$ & 16 & $\begin{array}{l}\text { Ali (2004) [27]; Adilo et al. (2005) [28]; Eshete et al. (2005) [29]; Luvanda } \\
\text { et al. (2007) [30]; Abtew et al. (2012) [9]; Agustino et al. (2011) [26]; } \\
\text { Gachathi and Eriksen (2011) [31]; Worku et al. (2011) [32]; Abdulla } \\
\text { (2013) [33]; Adam et al. (2013) [34]; Mekonnen et al. (2013) [35]; } \\
\text { Teshome and Abdi-Khalil (2013) [36]; Abdalla (2014) [37]; Abtew et al. } \\
\text { (2014) [38]; Salah (2014) [23]; Tilahun et al. (2015) [39]. }\end{array}$ \\
\hline Value chain & 10 & $\begin{array}{l}\text { Gebrehiwot et al. (2003) [40]; Lemenih and Teketay (2003) [41]; } \\
\text { Chikamai et al. (2005) [42]; Lemenih et al. (2007) [43]; Lemenih et al. } \\
\text { (2011) [44]; Tilahun et al. (2011) [45]; Eshete et al. (2012) [46]; Gebru et al. } \\
\text { (2014) [19]; Lemenih et al. (2014) [20,21]; Gessmalla et al. (2015) [47]; }\end{array}$ \\
\hline $\begin{array}{l}\text { Climate change } \\
\text { adaptation }\end{array}$ & 2 & Lemenih and Teketay (2004) [18]; Hassan et al. (2011) [12]; \\
\hline $\begin{array}{l}\text { Ecology and } \\
\text { sustainable } \\
\text { management }\end{array}$ & 23 & $\begin{array}{l}\text { Feleke (2004) [48]; Gebrehiwot et al. (2004) [49]; Tadesse and Mbogga } \\
\text { (2004) [50]; Gemedo-Dalle et al. (2005) [51]; Abiyu et al. (2006) [52]; } \\
\text { Ogbazghi et al. (2006) [53,54]; Hadden (2007) [55]; Tadesse et al. (2007) } \\
\text { [56]; Tilahun et al. (2007) [57]; Abiyu et al. (2010) [58]; Lemenih et al. } \\
\text { (2011) [59]; Woldeamanuel (2011) [60]; Abush (2012) [61]; Groenendijk } \\
\text { et al. (2012) [6]; Gelaye (2012) [62]; Worku et al. (2012) [63]; Dejene et al. } \\
\text { (2013) [64]; Lemenih et al. (2014) [20,21]; Alemu et al. (2015) [65]; Bekele } \\
\text { (2016) [66]; Yilma et al. (2016) [67]; Mokria et al. (2017) [16]. }\end{array}$ \\
\hline
\end{tabular}

\subsection{Value Chain}

A commodity chain, also known as value chain and production-consumption chain, comprises a comprehensive sequence of operations involved in the design, production, processing, storage and marketing of a product $[7,9,22,68-70]$. Commodity chains for aromatic resins included in the present study, frankincense and myrrh, can be divided into five distinct steps: harvesting, sorting, transporting, storage and, finally, marketing, at the village, district and national levels [12].

\subsubsection{Harvesting}

Poor households living in villages are the main collectors of aromatic resins [12]. They receive rice, sugar, tea, cooking oil and other necessities in the form of a loan from local traders in an agreement whereby they sell the resin to the creditor. The pastoralists also collect resins in passing together with other forest products, as encountered while herding livestock. There are two methods of harvesting both frankincense and myrrh: either by tapping the trees, or by collecting the natural exudate that results from injuries caused by animals, particularly goats and antelopes.

Resin collectors tap the Boswellia and Commiphora trees. The tapping is repeated in sequences three times by using either Mangaab (syn. Mengaf) or axe. They make incisions (wounds) on the stem or the trucks of trees about $1 \mathrm{~m}-1.5 \mathrm{~m}$ above the ground level in a first tapping, trees are wounded and wait for about one and half weeks; the trees then exude thin layers of resin. A second tapping is conducted on the same places by removing the thin resin layers exuded by the tree. Again after 1.5 weeks a third tapping is done. During the third tapping, the tree exudes more resin in order to protect itself from bacteria and insect attacks. When the resin dries, it is harvested from the tree or collected on the ground where it drops [12,22,56]. Repeating tapping increases the tree mortality [35].

\subsubsection{Sorting and Quality Control Criteria}

After the harvesting, both frankincense and myrrh resins are cleaned by removing bark, leaves, sand and other adulterants. The quality classification of the resin is based on the colour and the odour. Reddish or brownish myrrh is considered as grade one, while myrrh with dark colour or with bark particles is considered as low quality and usually sold in local markets for local use. White frankincense is graded as the best quality and darker one low quality. In Somalia, three different types 
of frankincense exist which can be distinguished based on colour and fragrance, and each one has a local name: Frankincense obtained from Boswellia frereana known as maidi is the best and the most expensive; frankincense obtained from $B$. sacra known as beyo is the second best, and frankincense obtained from B. neglecta is known as fooh has the lowest quality [12,71].

\subsubsection{Factors Hindering Aromatic Resin Production}

Lack of proper tapping methods, labour intensiveness in collecting and transporting the products, environmental challenges, low prices, lack of market regulation, and the inaccessibility of bank credit were considered as the most challenging factors constraining for the aromatic resin industry [35]. Results indicate that the main factors constraining the participation of aromatic resins production in Ethiopia were cultural factors (mentioned by $63 \%$ of the respondents), insufficient income $38 \%$ ), and woodland tenure issues $(27 \%)$, followed by regional policies $(20 \%)$ and lack of knowledge of production technology $19 \%$ [19].

\subsubsection{Market}

The Horn of Africa is a region characterized by a low number of formal farmer associations. There are, in effect, four identified aromatic market chains: The market chain of frankincense and myrrh comprises the collectors, local traders (middlemen), wholesalers and exporters [12].

The gums and resins market consists of many sellers and one or few buyers. In this situation, sellers of gums and resins often engage in price wars to attract the interest of a single or few buyers, thereby effectively decreasing the market price and increasing the quantity demanded. Owing to the buying power of monopolists, they are able to determine the market price they pay for gums and resins compared with buyers of same products in more competitive markets [59]. The resin collectors felt that the middlemen buying up the tree products were taking an undue share of the profit. Therefore, local producers of gums and resins often receive a minimal price, losing any power they earlier had over supply and demand. Markets ought to target more realistic and competitive transactions in a system that is more influenced by market forces of supply and demand. Another obstacle that also contributes to price distortions in the marketing chain is the lack of value addition from processing, including grading, sorting and packaging [14].

Internationally, the end-uses of aromatic resin are in the pharmaceutical industries, fragrance manufacturing being chiefly for incense and perfumery [46], and in the production of flavouring agents (e.g., for chewing gums) as listed in (Table 3). In Ethiopia between 1997 and 2010, the total quantity of aromatic resins exported amounted to 33,865 tons [35] as shown in Figure 2.

Table 3. The end-uses of frankincense and myrrh in local and international markets (modified from $[42,56])$.

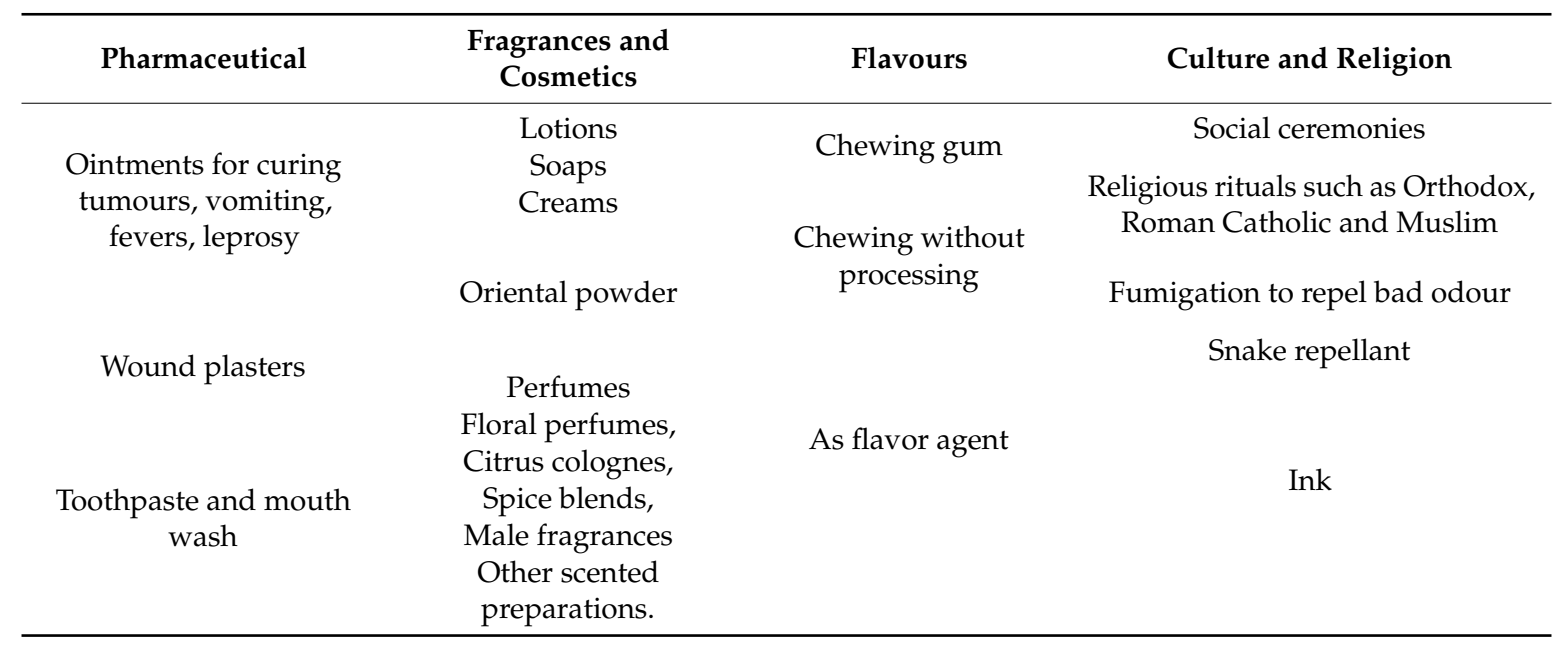


China, Europe, Japan, Middle East, North Africa and USA are the main importers of aromatic resins [72]. Compared to the production potentials of aromatic resins in the Horn of Africa, the amount of resins exported from the region is relatively small $[44,56]$. It has been estimated that the Rashad district of Southern Kordofan state alone has an average frankincense production potential of 8000 tons per year [73]. Between 1998 and 2007, Ethiopia exported about 3000 MT, Eritrea 400 MT, Kenya 1.5 MT and Somalia 1.2 MT of aromatic resins while the global demand for frankincense and myrrh was estimated at about 6000 MT per annum [39,44,53,72].

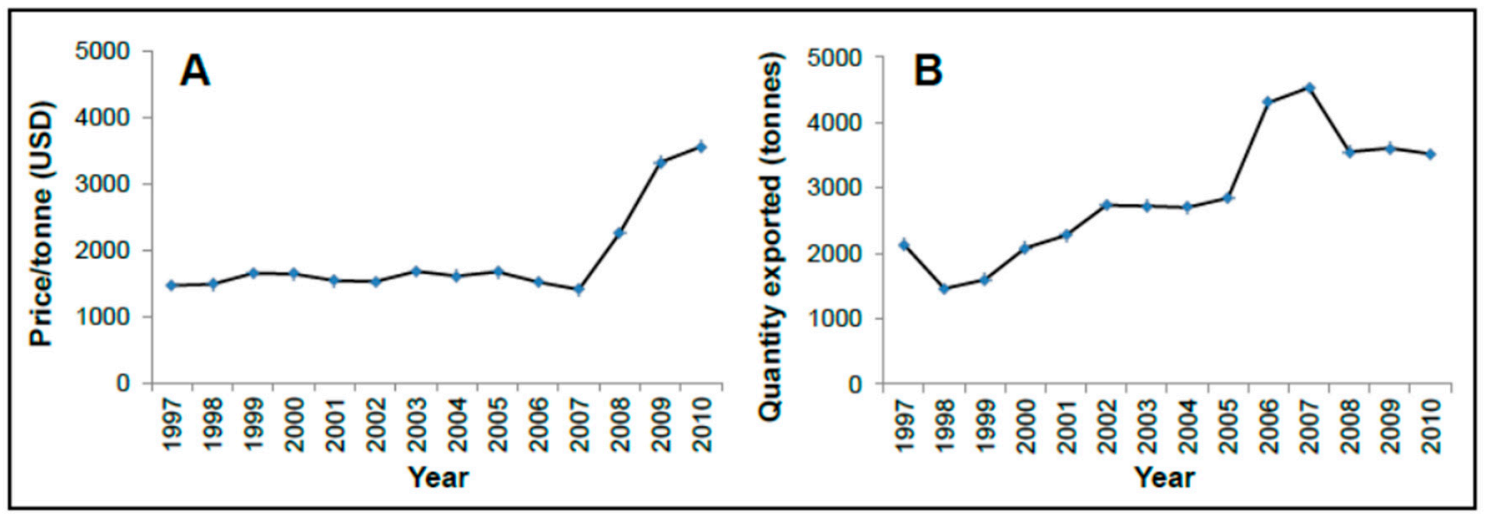

Figure 2. The price trend (A) and export quantity (B) of gums and aromatic resins in Ethiopia [74].

There is confusion in the statistical information on the supply and demand for aromatic resins in the international market as these products are often included in a diffuse group of "natural gums, resins and balsams"; also the accuracy of the export data is questionable because of unofficial trade across the borders and among the producing countries [40]. However, it has been found that myrrh contributes approximately thirty percent of the national aromatic resin and gum arabic production potential in Kenya, which was estimated to be 1050 tons per annum [30]. A similar study conducted in Wajir, north-eastern Kenya, found that, during the winter season (December-February), about 180 tons of frankincense and myrrh is transported out of the district per month, while during the summer season (June-Agugust) the corresponding amount is between 70 and 80 tons [12]. Statistical data sourced from the Ethiopian Revenues and Customs Authority indicate that both the price and the export quantity of gums and aromatic resins for the period (1997-2010) show a positive trend with respect to the national economy of Ethiopia (Figure 1) [74].

\subsection{Economic Contribution and Livelihood Security}

As multi-purpose tree species, Boswellia and Commiphora species not only provide resins but all their parts are used for different purposes. Among the important products of these species are fodder for browsing animals, especially goats and camels, craftwork, dyes, honey, and traditional medicines and rehabilitation of degraded lands [10].

Results indicate that aromatic resins contribute substantially to the rural household economy in the HoA $[38,40,45]$ despite the observed inefficiencies in value chains [74]. Resin products contribute to an average total of US\$ 350 in annual household income to the poorest households, $[9,12,40,74]$. Economic contribution of gums and resins in Ethiopia and Sudan is estimated at $14-23 \%$ of the rural household incomes generated from NTFPs [38]. In Ethiopia women in dryland communities earn also an average income of US $\$ 160$ per annum from frankincense-related activities [40]. A frankincense tapper can also receive a net income of US\$ 100 to150 per annum in Ethiopia [ibid]. Other studies indicated that gum and aromatic resin resources contribute substantially to the national economy in Ethiopia, despite the observed inefficiencies in value chains [35]. In the Nuba Mountains, Sudan, in 2007, frankincense obtained from B. papyrifera alone generated US\$153,000 [9]. 


\subsection{Ecology, Exploitation, Climate Change Adaptation, and Management}

\subsubsection{Ecology}

Different species of Boswellia and Commiphora (see Table 4) that bear aromatic resins, frankincense and myrrh, respectively, are found in the Horn of Africa region. The spatial elevation distribution of these genera ranges from 200 to $2000 \mathrm{~m}$ above sea level [44]. Boswellia and Commiphora species are found in harsh environments where the soil is shallow, about $20 \mathrm{~cm}$ deep and rocky, and on steep slopes, around gullies, on lime soils clay soil and sandy soils [12,40,71]. Frankincense is chiefly obtained from five species. Boswellia sacra Flueck and Boswellia frereana Birdw. are found in the Somali peninsula and grow commonly on almost bare rocks, whereas Boswellia papyrifera (Del) Hochst. grows on sandy soils in Eritrea, Ethiopia and Sudan. In addition, low-quality frankincense is obtained from Boswellia neglecta S. Moore and Boswellia ogadensis Vollesen in north-eastern Kenya, the Ogaden region in Ethiopia, and in Somalia [72].

Table 4. List of aromatic resin bearing trees and shrubs in the Horn of Africa by genus and species $[10,51]$.

\begin{tabular}{clcl}
\hline No. & \multicolumn{1}{c}{ Genus Boswellia } & No. & \multicolumn{1}{c}{ Genus Commiphora } \\
\hline 1 & B. frereana Birdw. & 1 & C. africana (A.Rich.) Engl. \\
2 & B. microphylla Chiov. & 2 & C. boranensis Vollesen \\
3 & B. neglecta S. Moore & 3 & C. corrugata J.B.Gillett \& Vollesen \\
4 & B. ogadensis Vollesen & 4 & C. cyclophylla Chiov. \\
5 & B.papyrifera (Del) Hochst. & 5 & C. erythraea (Ehrenb) Engl. \\
6 & B. pirrotae Chiov. & 6 & C. habessinica (Berg) Engl. \\
7 & B. rivae Engl. & 7 & C. hildebrandtii Engl. \\
8 & B. sacra Flueck. & 8 & C. guidotti Chiov. \\
& & 9 & C. kua (R.Br. Ex. Royle) Vollesen \\
& & 10 & C. monoica Vollesen \\
& & 11 & C. myrrha (Nees) Engl. \\
& & 12 & C.schimperi (Berg) Engl. \\
& & 13 & C. serrulata Engl. \\
& & 14 & C. truncata Engl. \\
\hline
\end{tabular}

There are also some other Boswellia species that exude frankincense but are not economically important (cf. Table 4). The total area covered by Boswellia papyrifera in Ethiopia is estimated at approximately 2.9 million ha, with annual resin production potential of over 300,000 MT [68].

The myrrh-producing Commiphora species are small trees or shrubs, some with short, thorny branches and some without thorns. The "true", and most expensive, myrrh is obtained from Commiphora myrrha (Nees) Engl. (syn. C. malmal). Interestingly, this particular tree is endemic within the Somali-speaking territory of the Horn of Africa, historically known as the land of Punt (north-eastern Kenya, the Ogaden region in eastern Ethiopia, and Somalia). Among the other Commiphora species, which yield low-quality myrrh resin, are the following: Commiphora habessinica (Berg) Engl. Commiphora holiziana Engl. Commiphora guidotti Chiov. (syn. Commiphora hadi), Commiphora erythraea (Ehrenb) Engl., Commiphora foliacea Sprague, Commiphora playfairii (Hook. fil.) Engl. and Commiphora serrulata Engl. [71]. However, the population of these species are reduced as result of tree cutting, low seed production and low seed germination caused by inappropriate tapping [75].

\subsubsection{Climate Change Adaptation and Management}

In response to the insufficiency of forest products, the rural communities adapt to climate change by developing different internal system that allow them to cope with the increasing scarcity of these products. Such internal systems include diversification of livelihood activities and tree growing on farmland [12]. Examples of new trends in coping strategies of pastoralists to climate change at community and household levels, in Somalia and north-eastern Kenya, include seeking off-farm wage 
employment as well as migration and resettlement [12,76]. The result extracted from the review data suggested a number of management methods being used such as fire control, harvesting regulation, appropriate tapping tools and improved tapping method and timing [44].

\section{Discussion}

The dryland resources in the Horn of Africa play a significant role in the livelihoods of the rural communities. The majority of the human population in sub-Saharan Africa, including the Horn of Africa, lives in rural areas and depends on subsistence crop and livestock production as principal means of living [3]. Over sixty percent of these people survive on less than US\$1 a day [77,78]. It is widely acknowledged that non-wood forest products (NWFPs) play a major role in rural livelihood security and national economy in the region.

For centuries, the pastoral and agro-pastoral communities living in this region relied on dryland resources also through harvesting and use of NWFPs $[79,80]$.

Frankincense and myrrh are age-old commercial NWFPs, which still remain commercially important products [40]. Aromatic resins are used in various industries, including pharmacology, cosmetics and perfumery, flavouring, etc. [81,82]. Aromatic resins provide significant revenues not only to households; national governments also generate a lot of hard currency in the related export trade [28]. The pastoralists in the region collect and sell frankincense and myrrh as an adaptation option when faced with climate-driven risks [12,83]. Throughout this region, Boswellia and Commiphora species provide both economic and ecological benefits and thus mitigate the climate change effects and enhance the related adaptation strategies [35,41]. Globally, over one billion households in extreme poverty rely on forest and forest related resources in the developing countries [7]. In particular, the open-access dryland vegetation is a key source of feed for the livestock [24]. Thus, the different kinds of products provided by the woodlands and wooded grasslands of the region are important in improving livelihoods and alleviating poverty of the rural communities in a sustainable way $[9,69,82,84]$. Boswellia and Commiphora spp. are the main dryland trees in the Horn of Africa region that yield aromatic resins [50] and a diverse range of other environmental and economic benefits to rural communities [23,75]. This also appears to be the case in a global perspective: for instance, poor rural households in Vietnam receive about $76 \%$ of their annual household income from the forest [54]. In Southern Africa in general, non-wood and NTFPs contribute between $20 \%$ and $40 \%$ of total rural household income [85].

Ecosystem degradation, over-exploitation of resources and deforestation are serious challenges in the Horn of Africa region because the arid and semi-arid lands are particularly susceptible to desertification and climate-driven negative environmental impacts [16,57].

The resin-producing species often grow on steep slopes and rocky sites. These species provide ecological services by protecting the soil, regulating the water flow, creating favourable micro-climate conditions and contributing to carbon sequestration. However, population growth, land conversion, poor regeneration capacity of the woody vegetation, overgrazing, fire, and over-exploitation of forest resources are the main factors accelerating the ecosystem degradation that also exacerbate the problems of sustainable production of both gums and resins caused by unsustainable tapping methods that damage the trees $[17,32,46]$.

Sustainable management of Boswellia and Commiphora species can greatly contribute to a healthy environment and supply a wide variety of goods and non-material ecosystem services.

Indicating how sustainable management and conservation of Boswellia and Commiphora species could be achieved, it was found in a particular case that $57 \%$ of the rural populations surveyed proposed resource protection by hiring forest guards, 40\% suggested reforestation of degraded sites, and $24 \%$ proposed fire control and fire-prevention training; local participation in forest management and conservation was also mentioned as a desired activity [43].

The NWFPs obtained from dry forests and woodlands in the Horn of Africa are not only a safety net for the pastoral and agro-pastoral communities, they also support local and global industries [3]. A particular study [86] confirmed that poor rural communities in the Amhara region in Ethiopia drive 
$39 \%$ of their household income from the forest. [87]. In another case it was concluded that forest resources contribute about $40 \%$ of the poor households' income [87].

However, the financial contribution and the entire socio-economic importance of dryland resources are commonly ignored in economic policies and development strategies in Africa, even if it is widely acknowledged that these resources can help rural communities in coping with poverty and seasonal food shortages and in adaptation to climate-driven environmental and social changes [13,82].

This study exemplifies how aromatic resin markets have developed progressively throughout the years with respect to social, climatic and cultural influences. However, it also identified constraints in the marketing channels for aromatic resins in the Horn of Africa that may contribute to low economic incentives for producers and traders. The marketing of aromatic resins requires special consideration, if the aromatic resin sector is to improve and contribute effectively to the economy of the area. The problem of an inadequate number of gums and resins associations and their limited lobbying capacity could be tackled, if the governments collaborated with all relevant stakeholders, so as to sensitise and motivate the gum and resin collectors to organise themselves and to actively participate in the work of their new associations.

The study highlights the importance of market knowledg to ensure that products from Boswellia and Commiphora species can be procured efficiently to enhance profitably; it is either non-existence or lacking in most areas. The bargaining power of frankincense and myrrh collectors could be enhanced by encouraging responsible resource associations to play an active role in market price determination. Such a mechanism could significantly contribute to minimizing the roles of middlemen and externalities in influencing the market price.

The role of middlemen and vendors is considered trustworthy as long as they engage in professional marketing ethics in their transactions with the smallholder farmers on the one hand, and the consumer on the other. Creation of formal, local wholesale and retail aromatic resin markets is part of the solution to this problem, but it would necessitate government intervention to improve some of the basic infrastructure, such as roads, power supply and telecommunication.

Lack of financial capacity of the communities, i.e., access to credit, land use subsidies etc. for farming purposes, hinders the activities of the farmers. Enhancing access to affordable finance requires implementation of appropriate policies to facilitate genuine participation of newly formed associations, in mobilizing savings and in guaranteeing the entry of private sector to provide credit facilities.

A peculiar contributing factor to price distortions in the marketing chain is the lack of value addition from processing, including grading, sorting and packaging. It is necessary to invest in proper marketing infrastructure, which involves pack houses and refrigerated vans. Our findings suggest that a disordered marketing chain is currently a major feature of the sector.

Although aromatic resins play a vital role in rural livelihood security in the Horn of Africa, the Boswellia and Commiphora species populations are threatened by inappropriate harvesting techniques and continued ecosystem degradation. It has been emphasized that the development of indigenous forest management has two equally important components: a strategy for enhancing rural livelihoods and improved management interventions for forest resources [49]. Insecure land rights are also a major challenge to all dryland development. For instance, a study in Sudan has shown that for any tree-based farming system, security of land tenure is extremely important, owing to the long-term production cycles of trees and to the general tendency of classifying natural forests as government property [88-90]. Such results also suggest that farmers who have secure land rights are engaged not only in managing natural trees but also in planting trees, especially those offering multiple products.

\section{Conclusions}

Aromatic resins play a vital role in the livelihood security of the rural people in the Horn of Africa. Pastoral and agro-pastoral communities in the region rely on the aromatic resins consisting of frankincense and myrrh. Boswellia and Commiphora trees exude resin during the dry season; therefore, harvesting of these products offers employment and revenue-earning opportunities outside the peak 
farming season. Aromatic resins are important not only for the local communities but also for national economies.

One of the main constraints for developing the management and utilisation of aromatic resins is the lack of market information for these products. Experience calls for duly recorded data connected to the harvesting and processing of aromatic resins, particularly in relation to volumes and prices. Presently, a large number of local procurers sell these products to only one or few buyers, typically to local retailers. This situation leads to low price levels. Markets ought to be pushed towards more dynamic and competitive transactions in a way that would enable the prices of aromatic resins be determined by market forces of supply and demand.

The existing aromatic resin value chains are thus mainly intermediary buyer-driven chains, led by big traders. It should be possible to enhance the bargaining power of aromatic resin collectors by encouraging their own associations to play an active role in market price determination. This mechanism could diminish the role of middlemen and externalities in market price determination. A complete value assessment for the sector is required, as well as human resource development covering training in tapping techniques, processing, packaging, and organizational development.

National investment programmes are needed to enhance value addition and market development and to stop the decline of the Boswellia and Commiphora resource base. These trees are valuable agents for enhancing community resilience and adaptation under the threat of negative effects of global climate change.

The current marketing channels for aromatic resins trade in the Horn of Africa is disorganised in most cases. The system lacks well-defined outlets for proper wholesale and retail markets. Local farmers in this region already express a willingness to adopt on a larger scale the use of Boswellia and Commiphora trees as an integrated component of land-use systems. This willingness should be supported by appropriate national and local policy and legislation reforms and by development programmes that would both secure the rights of local communities to these resources and contribute to their sustainable management. This would ultimately lead to maximal economic, social and environmental benefits from these resources and thus significantly contribute to sustainable livelihood improvement.

Author Contributions: B.A.H. designed the research for this paper and took the lead in collecting the data, analyzing and writing the paper. E.K.G. contributed to the analysis and interpretation of the results. O.L. commented and edited the paper. O.L., M.K. and R.J. supervised the findings of this work. All authors provided invaluable comments that helped shape the research, analysis and manuscript.

Funding: This research received no external funding.

Conflicts of Interest: The authors declare no conflict of interest.

\section{References}

1. White, F. The Vegetation of Africa, Natural Resources Research 20; United Nations Scientific and Cultural Organization (UNSCO): Paris, France, 1983.

2. Inter-Governmental Authority for Development (IGAD). IGAD State of the Region Report: Popular Version. In Formulation of IGAD Strategy and Medium-Term Implementation Plan 2016-2020; Inter-Governmental Authority for Development: Djibouti, Djibouti, 2016.

3. Chidumayo, E.N.; Gumbo, D.J. The Dry Forests and Woodlands of Africa: Managing for Products and Services; Earthscan: London, UK, 2010; p. 288.

4. Chikamai, B.; Kagobe, J. Reviews and Synthesis on the State of Knowledge of Boswellia Species and Commercialization of Frankincense in the Drylands of Eastern Africa: Country Report of Kenya; Executive Printer Ltd.: Nairobi, Kenya, 2002.

5. Ethiopian Revenues and Customs Authority (ERCA). Ethiopian Revenue and Custom 2010; ERCA: Addis Ababa, Ethiopia, 2010.

6. Groenendijk, P.; Eshete, A.; Sterk, F.J.; Zuidema, P.A.; Bongers, F. Limitations to sustainable frankincense production: Blocked regeneration, high adult mortality and declining populations. J. Appl. Ecol. 2012, 49, 164-173. [CrossRef] 
7. Sturgeon, T.J. How do we define value chains and production networks? IDS Bull. 2001, 32, 9-18. [CrossRef]

8. Voice of Djibouti. 2016. Available online: https://voiceofdjibouti.com/un-urges-eastern-africa-to-fund-moredevelopment-domestically/ (accessed on 30 June 2019).

9. Abtew, A.A.; Pretzsch, J.; Mohmoud, T.E.S.; Adam, Y.O. Commodity chain of frankincense from the dry woodlands of Nuba Mountains, South Kordofan State, Sudan. Small-Scale For. 2012, 11, 365-388. [CrossRef]

10. Chikamai, B.; Gachathi, N. Gum and resin resources in Isiolo District, Kenya: Ethnobotanical and reconnaissance survey. East Afr. Agric. For. J. 1994, 59, 345-351. [CrossRef]

11. Coad, L.; Campbell, A.; Miles, L.; Humphries, K. The Costs and Benefits of Protected Areas for Local Livelihoods: A Review of the Current Literature; UNEP World Conservation Monitoring Centre: Cambridge, UK, 2008.

12. Hassan, B.; Glover, E.K.; Luukkanen, O.; Chikamai, B.; Jamnadass, R.; Iiyama, M.; Kanninen, M. The Role of Boswellia and Commiphora species in Rural Livelihood Security and Climate change adaptafion in the Horn of Africa: Case study of northeastern Kenya. Int. J. Soc. For. 2011, 4, 86-112.

13. Laird, S.A.; Awung, G.L.; Lysinge, R.J.; Ndive, L.E. The interweave of people and place: Biocultural diversity in migrant and indigenous livelihoods around Mount Cameroon. Int. For. Rev. 2011, 13, 275-293. [CrossRef]

14. Chikamai, B.; Tchatat, M.; Tieguhong, J.C.; Ndoye, O. Forest Management for Non-Wood Forest Products and Services in sub-Sahara Africa. Discov. Innov. 2009, 21, 50-59. [CrossRef]

15. Didita, M.; Yadessa, A. Non-wood Forest Products: Potentials and Constraints in Bale, Southeast Ethiopia. In Proceedings of the Conservation of Genetic Resources of Non-Timber Forest Products in Ethiopia, Addis Ababa, Ethiopia, 5-6 April 2004; p. 113.

16. Mokria, M.; Tolera, M.; Sterck, F.J.; Gebrekirstos, A.; Bongers, F.; Decuyper, M.; Sass-Klaassen, U. The frankincense tree Boswellia neglecta reveals high potential for restoration of woodlands in the Horn of Africa. For. Ecol. Manag. 2017, 385, 16-24. [CrossRef]

17. Ogbazghi, W. The Distribution and Regeneration of Boswellia papyrifera (Del.) Hochst. Tropical Resource Management Papers No. 35; Wageningen University: Wageningen, The Netherlands, 2001; p. 131.

18. Lemenih, M.; Teketay, D. Integrategrating Natural Gum and Resin Production with Biodiversity Conservation and Desertification Control and Adapting to Climate Change in Drylands of Ethiopia. In Proceedings of the Conservation of Genetic Resources of Non-Timber Forest Products in Ethiopia, Addis Ababa, Ethiopia, 5-6 April 2004; p. 41.

19. Gebru, Y.; Ewnetu, Z.; Kassa, H.; Padoch, C. Determinants of producers' participation in gums and resins value chains from dry forests and analysis of marketing channels in northwestern and southern Ethiopia. For. Trees Livelihoods 2014, 23, 54-66. [CrossRef]

20. Lemenih, M.; Arts, B.; Wiersum, K.F.; Bongers, F. Modelling the future of Boswellia papyrifera population and its frankincense production. J. Arid Environ. 2014, 105, 33-40. [CrossRef]

21. Lemenih, M.; Wiersum, K.F.; Woldeamanuel, T.; Bongers, F. Diversity and dynamics of management of gum and resin resources in ethiopia: A trade-off between domestication and degradation. Land Degrad. Dev. 2014, 25, 130-142. [CrossRef]

22. Leakey, R.R.; Tchoundjeu, Z.; Schreckenberg, K.; Shackleton, S.E.; Shackleton, C.M. Agroforestry tree products (AFTPs): Targeting poverty reduction and enhanced livelihoods. Int. J. Agric. Sustain. 2005, 3, 1-23. [CrossRef]

23. Salah, Y.M.S. The Role of Indigenous Gums and Resins in Pastoralists' Livelihood Security and Climate Change Adaptation in Garba Tula Area of Northern Kenya; Early Career Fellowship Programme: Brighton, UK, 2014.

24. Farah, A. The Milk of the Boswellia Forest: Frankincense Production among the Pastoral Somali; Research Programme on Environmental Policy and Society, EPOS, Department of Social and Economic Geography, Upsala University: Uppsala, Sweden, 1994.

25. Moher, D.; Liberati, A.; Tetzlaff, J.; Altman, D.G. The PRISMA Group. Preferred Reporting Items for Systematic Reviews and Meta-Analyses: The PRISMA Statement. PLoS Med. 2009, 6, e1000097. [CrossRef] [PubMed]

26. Agustino, S.; Mataya, B.; Senelwa, K.; Achigan-Dako, E.G. Non-wood forest products and services for socio-economic development. In A Compendium for Technical and Professional Forestry Education; The African Forest Forum: Nairobi, Kenya, 2011.

27. Ali, I.Y. The Economics of Boswellia papyrifera in South Kordofan. Master's Thesis, University of Khartoum, Sudan, North Africa, 2004. 
28. Adilo, M.; Woldemariam, T.; Yadessa, A. Counting on forests: Non-timber forest products and their role in the households and national economy in Ethiopia. In Proceedings of the 8th Annual Conference of Agricultural Economics Society of Ethiopia, Addis Ababa, Ethiopia, 24-26 February 2005.

29. Eshete, A.; Teketay, D.; Hulten, H. The socio-economic importance and status of populations of Boswellia papyrifera (Del.) Hochst. in northern Ethiopia: the case of North Gonder Zone. For. Trees Livelihoods 2005, 15, 55-74.

30. Luvanda, A.M.; Mulugeta, S.K.; Choge, B.N.; Chikamai, A.M.A.; Alhedy, L.; Mbwambo, M.A. The role of boswellia species and frankincense in the livelihood of local communities in Eastern Africa. Discov. Innov. 2007, 19, 398-403.

31. Gachathi, F.N.; Eriksen, S. Gums and resins: The potential for supporting sustainable adaptation in Kenya's drylands. Clim. Dev. 2011, 3, 59-70. [CrossRef]

32. Worku, A.; Lemenih, M.; Fetene, M.; Teketay, D. Socio-Economic Importance of Gum and Resin Resources in the Dry Woodlands of Borana, Southern Ethiopia. For. Trees Livelihoods 2011, 20, 137-156. [CrossRef]

33. Abdulla, A.M. Non-timber Forest Products and Food Security: The Case of Yabelo Woreda, Borana Zone, Ethiopia. Food Sci. Qual. Manag. 2013, 22, 9-22.

34. Adam, Y.; Pretzsch, J.; Pettenella, D. Contribution of non-timber forest products livelihood strategies to rural development in drylands of Sudan: Potentials and failures. Agric. Syst. 2013, 117, 90-97. [CrossRef]

35. Mekonnen, Z.; Worku, A.; Yohannes, T.; Bahru, T.; Mebratu, T.; Teketay, D. Economic contribution of gum and resin resources to household livelihoods in selected regions and the national economy of Ethiopia. J. Plant People Appl. Res. 2013, 11, 271-288.

36. Teshome, B.; Abdi-Khalil, E. Determinants and patterns of income diversification among smallholder farmers in Akaki district, Ethiopia. J. Econ. Int. Finance 2013, 2, 68-78.

37. Abdalla, A.A. Some Socio-Economic Aspects of Boswellia papyrifera and resin production in Blue Nile State-Sudan. J. Nat. Resour. Environ. Stu 2014, 2, 32-38.

38. Abtew, A.A.; Pretzsch, J.; Secco, L.; Mohamod, T.E. Contribution of Small-Scale Gum and Resin Commercialization to Local Livelihood and Rural Economic Development in the Drylands of Eastern Africa. Forests 2014, 5, 952-977. [CrossRef]

39. Tilahun, M.; Vranken, L.; Muys, B.; Deckers, J.; Gebregziabher, K.; Gebrehiwot, K.; Mathijs, E. Rural households' demand for frankincense forest conservation in Tigray, Ethiopia: A contingent valuation analysis. Land Degrad. Dev. 2015, 26, 642-653. [CrossRef]

40. Gebrehiwot, K.; Muys, F.B.; Haile, M.; Mitloehner, R. Introducing Boswellia papyrifera (Del.) Hochst and its non-timber forest product, frankincense. Int. For. Rev. 2003, 5, 348-353. [CrossRef]

41. Lemenih, M.; Teketay, D. Frankincense and myrrh resources of Ethiopia: I distribution, production, opportunities for dryland development and research needs. SINET Ethiop. J. Sci. 2003, 26, 63-72. [CrossRef]

42. Chikamai, B.; Ngethe, R.; Quresh, A. Production and marketing of Gum resins in Kenya: Network for Natural Gums and Resins in Africa (NGARA); FAO/NGARA: Nairobi, Kenya, 2005.

43. Lemenih, M.; Feleke, S.; Tadesse, W. Constraints to smallholders' production of frankincense in Metema district, North-western Ethiopia. J. Arid Environ. 2007, 71, 393-403. [CrossRef]

44. Lemenih, M.; Kassa, H. Challenges and forest-based opportunities in the drylands of Ethiopia. In Opportunities and Challenges for Sustainable Production and Marketing of Gums and Resins in Ethiopia; Lemenih, M., Kassa, H., Eds.; Center for International Forestry Research (CIFOR): Bogor, Indonesia, 2011; pp. 1-12.

45. Tilahun, M.; Muys, B.; Mathijs, E.; Kleinn, C.; Olschewski, R.; Gebrehiwot, K. Frankincense yield assessment and modeling in closed and grazed Boswellia papyrifera woodlands of Tigray, Northern Ethiopia. J. Arid Environ. 2011, 75, 695-702. [CrossRef]

46. Eshete, A.; Sterck, F.J.; Bongers, F. Frankincense production is determined by tree size and tapping frequency and intensity. For. Ecol. Manag. 2012, 274, 136-142. [CrossRef]

47. Gessmalla, A.F.; Raddad, E.Y.A.; Ibrahim, G.E.A. Effects of tapping date, tapping direction and elevation on resin yield from Boswellia papyrifera in the Blue Nile State, Sudan. Natural Resources, Agricultural Development and Food Security (NAF-IRN). NAF Int. Work. Pap. Ser. 2015, 15, 14.

48. Feleke, S. Natural gum producing trees of Ethiopia: Distribution, types and chemistry of gum. In Proceedings of the National Workshop on Non-Timber Forest Products in Ethiopia, Addis Abeba, Ethiopia, 5-6 April 2004; Ethiopian Agricultural Research Organization: Amibara, Ethiopia, 2004. 
49. Gebrehiwot, K.; Muys, B.; Haile, M.; Mitloehner, R. Population Decline of Boswellia papyrifera and Associated Species in Dry Forests of Northern Ethiopia and Rehabilitation Efforts. In Proceedings of the Conservation of Genetic Resources of Non-Timber Forest Products in Ethiopia, Addis Ababa, Ethiopia, 5-6 April 2004; p. 53.

50. Tadesse, W.; Mbogga, M. Conservation of Genetic Resources of Non Timber Forest Products in Ethiopia. In Proceedings of the National Workshop on Non-Timber Forest Products in Ethiopia, Addis Abeba, Ethiopia, 5-6 April 2004; Ethiopian Agricultural Research Organization: Amibara, Ethiopia, 2004.

51. Gemedo-Dalle, T.; Maass, B.L.; Isselstein, J. Plant biodiversity and ethnobotany of Borana pastoralists in Southern Oromia, Ethiopia. Econ. Bot. 2005, 59, 43-65. [CrossRef]

52. Abiyu, A.; Vacik, H.; Glatzel, G. Population viability risk management applied to Boswellia papyrifera (Del.) Hochst in North-eastern Ethiopia. J. Drylands 2006, 1, 98-107.

53. Ogbazghi, W.; Rijkers, T.; Wessel, M.; Bongers, F. Distribution of the frankincense tree Boswellia papyrifera in Eritrea: The role of environment and land use. J. Biogeogr. 2006, 33, 524-535. [CrossRef]

54. Ogbazghi, W.; Bongers, F.J.; Rijkers, T.; Wessel, M. Population structure and morphology of the frankincense tree Boswellia papyrifera along an altitude gradient in Eritrea. J. Drylands 2006, 1, 85-94.

55. Hadden, R.L. The Geology of Somalia: A Selected Bibliography of Somalian Geology, Geography and Earth Science; Army Topographic Engineering Center: Alexandria VA, USA, 2007.

56. Tadesse, W.; Desalegn, G.; Alia, R. Natural gum and resin bearing species of Ethiopia and their potential applications. For. Syst. 2007, 16, 211-221. [CrossRef]

57. Tilahun, M.; Olschewski, R.; Kleinn, C.; Gebrehiwot, K. Economic analysis of closing degraded Boswellia papyrifera dry forest from human interventions-A study from Tigray, Northern Ethiopia. For. Policy Econ. 2007, 9, 996-1005. [CrossRef]

58. Abiyu, A.; Bongers, F.; Eshete, A.; Gebrehiwot, K.; Kindu, M.; Lemenih, M.; Sterck, F. Incense woodlands in Ethiopia and Eritrea: Regeneration problems and restoration possibilities. In Degraded Forests in Eastern Africa: Management and Restoration; Earthscan: Oxford, UK, 2010; pp. 133-152.

59. Lemenih, M.; Bonger, F. Dry forests of Ethiopia and their silviculture. In Silviculture in the Tropics, Tropical Forestry; Gunter, S., Weber, M., Stimm, B., Mosandi, R., Eds.; Springer: Berlin, Germany, 2011; pp. 261-272.

60. Woldeamanuel, T. Dryland Resources, Livelihoods and Institutions: Diversity and Dynamics in Use and Management of Gum and Resin Trees in Ethiopia; Wageningen University: Wageningen, The Netherlands, 2011; p. 169.

61. Abush, Z. Phenology and Genetic Diversity of Boswellia Papyrifera (Del.) Hochst. Ph.D. Thesis, Addis Ababa University, Addis Ababa, Ethiopia, 2012.

62. Gelaye, M.T. Restoration and Sustainable Management of Frankincense Forests in Ethiopia. Ph.D. Thesis, Free University of Amsterdam, Amsterdam, The Netherlands, 2012.

63. Worku, A.; Teketay, D.; Lemenih, M.; Fetene, M. Diversity, regeneration status, and population structures of gum and resin producing woody species in Borana, Southern Ethiopia. For. Trees Livelihoods 2012, 21, 85-96. [CrossRef]

64. Dejene, T.; Lemenih, M.; Bongers, F. Manage or convert Boswellia woodlands? Can frankincense production payoff? J. Arid Environ. 2013, 89, 77-83. [CrossRef]

65. Alemu, B.; Eshetu, Z.; Garedew, E.; Kassa, H. Assessment of vegetation characteristics and production of Boswellia papyrifera woodlands in north western lowlands of Ethiopia. Sky J. Agric. Res. 2015, 4, 8-13.

66. Bekele, A.A. Conservation Genetics of the Frankincense Tree; Wageningen University: Wageningen, The Netherlands, 2016.

67. Yilma, Z.; Worku, A.; Mohammed, O.; Girma, A.; Dejene, T.; Eshete, A.; Tadesse, W. Status of populations of gum and resin bearing and associated woody species in Benishangul-Gumuz National Regional State, western Ethiopia: Implications for their sustainable management. For. Trees Livelihoods 2016, 25, 1-15. [CrossRef]

68. Luukkanen, O.; Hassan, B.A.; de Leeuw, J. Gum Arabic and aromatic resins. In A Review of Best Practices for Selected Biodiversity-Based Value Chains that Promote Pro-poor Conservation in the Horn of Africa; De Leeuw, J., Carsan, S., Koech, G., Yayé, A.D., Nyongesa, J., Eds.; World Garoforestry Center (ICRAF): Nairobi, Kenya, 2017; p. 134.

69. Marshall, E.; Newton, A.C.; Schreckenberg, K. Commercialisation of non-timber forest products: First steps in analysing the factors influencing success. Int. For. Rev. 2003, 2, 128-137. [CrossRef]

70. Ribot, J.C. Theorizing access: Forest profits along Senegal's charcoal commodity chain. Dev. Chang. 1998, 29, 307-341. [CrossRef] 
71. Chikamai, B.N.; Casadei, E.; Coppen, J.J.W.; Abdel Nour, H.O. A Review of Production, Markets and Quality Control of Gum Arabic in Africa; FAO, Forestry Department: Roma, Italy, 1996.

72. Chupezi, T.J.; Ndoye, O.; Tchatat, M.; Chikamai, B. Processing and marketing of non-wood forest products: Potential impacts and challenges in Africa. Discov. Innov. (Sfm Spec. Ed.) 2009, 21, 60-65. [CrossRef]

73. El Tahir, B.A.; Gebauer, J. Non-timber Forest Products: Opportunities and Constraints for Poverty Reduction in the Nuba Mountains, South Kordofan, Sudan. In Proceedings of the Conference on International Agricultural Research for Development. Deutcher Tropentag, Berlin, Germany, 5-7 October 2004.

74. Marshall, E.; Schreckenberg, K.; Newton, A.C. Commercialization of non-timber forest products: Factors influencing success-lessons learned from Mexico and Bolivia and policy implications for decision-makers. A final output of project R7925. Int. For. Rev. 2006, 8, 368-370.

75. Rijkers, T.; Ogbazghi, W.; Wessel, M.; Bongers, F. The effect of tapping for frankincense on sexual reproduction in Boswellia papyrifera. J. Appl. Ecol. 2006, 43, 1188-1195. [CrossRef]

76. Agrawal, A. Greener Pastures: Politics, Markets, and Community among a Migrant Pastoral People; Duke University Press: Durham, NC, USA, 1999; p. 240.

77. Kaimowitz, D. Forest law enforcement and rural livelihoods. Int. For. Rev. 2003, 5, 199-210. [CrossRef]

78. Shackleton, C.M.; Shackleton, S.E.; Buiten, E.; Bird, N. The importance of dry woodlands and forests in rural livelihoods and poverty alleviation in South Africa. For. Policy Econ. 2007, 9, 558-577. [CrossRef]

79. Kandagor, D.R. Rethinking Pastoralism and African Development: A Case Study of the Horn of Africa; Egerton University: Njoro-Kenya, Kenya, 2005.

80. Teshome, B.; Kassa, H.; Padoch, C.; Mohammed, Z. Determinants Level of Income of Gums and Resins in the Dry Forest Areas and the Contribution to Different Socio Economic in Northwestern and Southern Ethiopia. J. Resour. Dev. Manag. 2016, 25, 31-37.

81. FAO. Guidelines on Sustainable Forest Management in Drylands of Sub-Saharan Africa. In Arid Zone Forests and Forestry; Working Paper 1; FAO: Rome, Italy, 2010.

82. Teshome, B.; Kassa, H.; Padoch, C.; Mohammed, Z. Contribution of Dry Forest Products to Household Income and Determinants of Forest Income Levels in the Northwestern and Southern Lowlands of Ethiopia. Nat. Resour. 2015, 6, 331-338. [CrossRef]

83. Ruz, R.V.; Harasawa, H.; Lal, M.; Wu, S.; Anokhin, Y.; Punsalmaa, B.; Honda, Y.; Jafari, M.; Li, C.; Ninh, N.H. Climate Change 2007: Impacts, Adaptation and Vulnerability. In Contribution of Working Group II to the Fourth Assessment Report of the Intergovernmental Panel on Climate Change; Parry, M., Canziani, O., Palutikof, J., van der Linden, P., Hanson, C., Eds.; Cambridge University Press: Cambridge, UK, 2007; pp. 433-467.

84. Challinor, A.; Wheeler, T.; Garforth, C.; Craufurd, P.; Kassam, A. Assessing the vulnerability of food crop systems in Africa to climate change. Clim. Chang. 2007, 83, 381-399. [CrossRef]

85. Touré, S. Gum Arabic and Gum Resins; ITC Market News Service; International Trade Centre: Geneva, Switzerland, 2009; p. 39.

86. Mamo, G.; Sjaastad, E.; Vedeld, P. Economic dependence on forest resources: A case from Dendi District, Ethiopia. For. Policy Econ. 2007, 9, 916-927. [CrossRef]

87. Cavendish, W. Empirical Regularities in the Poverty-Environment Relationship of African Rural Households; The Centre for the Study of African Economies Working Paper Series; Centre for the Study of African Economies: Oxford, UK, 1999; p. 105.

88. Fahmi, M.K.M.; Sanjak, E.; Kanninen, M.; Luukkanen, O.; Kalame, F.B.; Eltayeb, A.M. Determinants and constraints of integrating natural acacias into mechanised rain-fed agricultural schemes Sennar State, Sudan. GeoJournal 2015, 80, 555-567. [CrossRef]

89. Glover, E.K. Tropical Dryland Rehabilitation: Case Study on Participatory Forest Management in Gedaref, Sudan. Ph.D. Thesis, University of Helsinki, Helsinki, Finland, 2005; p. 185.

90. Luukkanen, O.; Katila, P.; Elsiddig, E.; Glover, E.K.; Sharawi, H.; Elfadl, M. Partnership between Public and Private Actors in Forest Sector Development: Options for Dryland Africa Based on Experiences from Sudan, with Case Studies on Laos, Nepal, Vietnam, Kenya, Mozambique and Tanzania; Tropical Forestry Reports; Viikki Tropical Resources Institute, University of Helsinki: Helsinki, Finland, 2006; Volume 31, pp. 1-119.

(C) 2019 by the authors. Licensee MDPI, Basel, Switzerland. This article is an open access article distributed under the terms and conditions of the Creative Commons Attribution (CC BY) license (http://creativecommons.org/licenses/by/4.0/). 